\title{
KEMAMPUAN SISWA BERMAIN DRAMAMELALUI \\ MODEL ROLLE PLAYING DI KELAS V SD INPRES 2 RUSAKENCANA KABUPATEN BANGGAI PROVINSI SULAWESI TENGAH
}

\author{
Sumarni Mohamad \\ Ratna Marianingsih \\ Jurusan Pendidikan Guru Sekolah Dasar Fakultas Ilmu Pendidikan \\ Universitas Negeri Gorontalo \\ ABSTRAK
}

Penelitian ini bermaksud untuk mendeskripsikan tingkat kemampuan siswa dalam bermain drama. Jenis penelitian yang digunakan adalah penelitian deskriptif kualitatif. Hasil penelitian menunjukkan bahwa kemampuan siswa bermain drama telah mencapai tujuan pembelajaran. Hal ini ditunjukkan pada observasi kemampuan siswa yaitu, 12 siswa atau 60\% siswa mampu bermain drama, 8 siswa atau $40 \%$ siswa kurang mampu dan $0 \%$ siswa tidak mampu.Dari hasil penelitian dapat disimpulkan bahwa teknik guru dalam pembelajaran drama sudah tepat dan mencapai tujuan pembelajaran

Kata Kunci: Kemampuan Bermain Drama, Model Rolle Playing

\section{A.PENDAHULUAN}

Drama merupakan materi ajar bahasa indonesia di kelas $\mathrm{V}$ yang mengharapkan keaktifan dalam pembelajaran. Seorang guru di haruskan dapat menciptakan suasana yang menyenangkan. Kreatifitas guru akan sangat mendukung dalam peningkatan hasil belajar siswa. Sehingga keaktifan siswa dalam proses KBM berlangsung sesuai dengan harapan.

Dalam bermain drama, siswa tidak hanya di tuntut untuk memahami materi ajar tentang drama, tetapi mereka harus mampu bermain drama dengan memerankan salah satu tokoh yang ada dalam cerita. Dengan bermain drama, siswa dapat mengembangkan keterampilan berbicara sehingga dapat membiasakan diri berkomunikasi dengan baik. Selain itu mereka dapat pula menyalurkan bakat akting yang ada dalam diri masing-masing.

Akan tetapi, Perasaan malu dan kurang percaya diri sering terjadi pada beberapa siswa di kelas V SD Inpres 2 Rusakencana. Perasaan ini dapat menghambat siswa untuk melakukan komunikasi dengan baik. Siswa juga akan kesulitan 
membangun interaksi dengan temanteman dan sekitarnya. Sehingga kemampuan mereka dalam bermain drama tidak nampak secara maksimal.

Untuk mengatasinya, seorang guru harus dapat menggunakan teknik yang tepat. Teknik bermain peran atau RolePlaying merupakan salah satu teknik yang dapat memotivasi siswa untuk aktif dalam belajar drama. Melalui teknik ini, siswa tidak hanya berdiam diri mendengarkan guru menjelaskan materi ajar, tetapi juga dapat mengembangkan keterampilan berbicara melalui diskusi dan bermain peran.

\section{B.KAJIAN TEORI}

\section{Pengertian Kemampuan}

Menurut Yusdi

"kemampuan adalah kecakapan atau potensi seseorang individu dalam melakukan atau mengerjakan beragam tugas dalam suatu pekerjaan atau penilaian atas tindakan seseorang". Abas (2013:6) juga menjelaskan "kemampuan adalah kesanggupan, kecakapan, kekuatan seseorang . seseorang dikatakan mampu jika ia dapat melakukan sesuatu yang harus dilakukan. Kemampuan adalah kecakapan individu untuk melakukan beragam tugas dalam suatu pekarjaan".

Dari pengertian di atas dapat disimpulkan bahwa kemampuan merupakan potensi seseorang berupa kecakapan, Kekuatan dan kesanggupan dalam melakukan suatu pekerjaan atau penilaian atas tindakan yang dilakukan.

\section{Pengertian Drama}

Berdasarkan etimologi (asal bentuk kata), kata drama berasal dari bahasa yunani dram yang berarti gerak. Tontonan drama menonjolkan percakapan (dialog) dan gerak-gerik dari para pemain (akting). Percakapan dan gerak-gerik itu memeragakan cerita yang tertulis di dalam naskah. Dengan demikian penonton dapat melihat dan menikmati langsung cerita tanpa harus membayangkan (Wiyanto, 2005:1).Menurut Yustinah dan iskak, bahwa "drama adalah suatu karangan yang berbentuk dialog/percakapan antara para pemainnya"(2008:28). Drama merupakan suatu bentuk karya sastra yang berbentuk dialog/ 
percakapan. Di dalam dialog tersebut nampak alur cerita dan juga amanat yang ingin di sampaikan melalui gerak gerik pemain.Wiyanto (2005 :2) mengemukakan "drama adalah semua bentuk tontonan yang mengandung cerita dan dipertunjukkan di depan orang banyak". Oleh karenanya, melalui drama seseorang tidak perlu lagi membayangkan peristiwa-peristiwa yang terjadi, gerak-gerik tokoh, dan percakapan yang ada dalam cerita karena semua telah ditampilkan oleh para pemainnya.

Dari penjelasan tersebut, dapat di artikan bahwa drama adalah suatu bentuk seni berupa dialog/percakapan yang menggambarkan kehidupan manusia dalam bertingkah laku, mengandung amanat yang akan di sampaikan melalui peran dan dipertunjukkan untuk dinikmati oleh banyak orang.

\section{Unsur-unsur Drama}

Unsur-unsur drama meliputi:

\section{a. Naskah Drama (Judul dan Tema)}

Judul adalah kepala karangan atau nama yang dipakai untuk buku atau bab dalam buku yang dapat menyiratkan isi buku tersebut. Sedangkan tema dapat diartikan sebagai ide pokok atau gagasan utama yang mendasari cerita sehingga menjadi pangkal tolak pengarang dalam memaparkan karya sastra yang diciptakannya.

\section{b. Alur / Plot}

Alur/plot adalah jalan cerita dari sebuah pertunjukkan drama. Waluyo (Tukan, 2007:45) mengemukakan bahwa peristiwaperistiwa drama dapat dikategorikan sebagai berikut:

1. Exposition atau awal cerita

2. Risingaction atau pertikaian awal

3. Klimaks

4. Resolusi atau fallingaction

5. Catastrope atau Keputusan

c. Pemain (tokoh cerita dan perwatakan)

Menurut Suryanto dan Haryanta (2007:51), bahwa tokoh menempati kedudukan yang sangat penting dalam drama. Tokoh merupakan penggambaran dari berbagai karakter manusia yang dijumpai dalam kehidupan seharihari. 
Yustinah dan Iskak (2008:28) mengemukakan bahwa tokoh-tokoh dalam drama terdiri atas:

1. Protagonis, tokoh yang berperan utama sebagai tokoh idaman/tokoh sentral.

2. Antagonis, tokoh yang berperan sebagai penantang tokoh utama, penentang ide, atau penentang sikap-sikap tokoh utama.

3. Figuran, pemeran pembantu, yakni tokoh yang kehadirannya mendampingi tokoh utama atau tokoh pelengkap. Kadang-kadang, orang ketiga merupakan sumber konflik cerita drama.

\section{d. Latar atau Setting}

Latar adalah lingkungan tempat berlangsungnya peristiwa yang dapat dilihat, di dalamnya terdapat aspek waktu, iklim, dan periode sejarah. Latar mendukung dan menguatkan tindakan tokohtokoh cerita. Latar dapat memberikan kesan realistis kepada pembaca atau penontonyang membuat cerita seolah-olah sungguh ada dan benarbenar terjadi (Nurgiyantoro dalam Crespo: 2011).

\section{e. Amanat}

Amanat atau pesan adalah materi yang terkandung dalam tema untuk disampaikan kepada para pembaca/penonton yang datangnya selalu dari pencipta atau penyaji (Satoto, 2012:50).

\section{Langkah-langkah bermain drama}

Langkah-langkah bermain drama meliputi:

1. Membuat naskah drama.

2. Membuat tujuan / pesan dari drama yang di mainkan.

3. Membuat naskah drama yang baik dan menarik sesuai dengan karakternya.

4. Melakukan revisi pada bagian yang di anggap kurang sesuai.

5. Membagi para pemeran tokoh drama.

6. Melakukan latihan sesuai tokoh yang diperankan.

\section{Model Rolle Playing}

Adapun langkah-langkah bermain drama (Role Playing) yang 
harus dilakukan guru di kelas adalah sebagai berikut:

1. Guru melakuakan apersepai yang dapat membawa siswa masuk dalam bermain drama.

2. Guru menjelaskan materi tentang drama.

3. Guru memberikan teks drama yang telah di fotokopy kepada siswa.

4. Guru membagi siswa dalam beberapa kelompok, meminta mereka memahami isi teks drama.

5. Siswa di minta untuk berdiskusi tentang hal-hal yang belum dipahami.

6. Guru mendemonstrasikan cara memerankan tokohtokoh drama.

7. Bersama-sama, siswa diminta berlatih memerankan berbagai macam ekspresi (senang, sedih, menangis, tertawa dll).

8. Siswa bermain drama sesuai dengan teks.

9. Evaluasi akhir dari guru, setiap kelompok menampilkan drama sesuai dengan naskah.

\section{C.METODE PENELITIAN}

Penelitian ini dilaksanakan di SD Inpres 2 Rusakencana Kecamatan Toili Kabupaten Banggai Provinsi Sulawesi Tengah. Penelitian dilakukan dengan memfokuskan pada implementasi teknik roleplaying pada materi drama di kelas V SD Inpres 2 Rusakencana. Lokasi penelitian dipilih karena lokasi ini merupakan tempat ditemukannya kasus yang sesuai dengan tujuan penelitian.Pendekatan penelitian yang digunakan yaitu penelitian kualitatf. Data dalam penelitian ini merupakan data yang benar-benar diambil peneliti berdasarkan informasi yang diperoleh dari informan yang mengetahui masalah yang menjadi fokus penelitian ini. Sumber data diperoleh peneliti terdiri dari data primer dan data skunder.Prosedur pengumpulan databerupa observasi, wawancara dan dokumentasi.Analisis data menggunakan data dari hasil obsevasi dan wawancara. 


\section{D.HASIL PENELITIAN DAN PEMBAHASAN \\ Temuan Umum Penelitian}

Secara umum, peneliti telah memperoleh gambaran bahwa kemampuan siswa bermain drama pada kelas V SD Inpres 2 Rusakencana sudah cukup baik. 12 orang dari jumlah siswa dianggap mampu memerankan salah satu tokoh dalam drama. Namun ada beberapa siswa yang kurang mampu bahkan belum mampu dalam bermain drama. Oleh karena itu, bimbingan guru masih sangatlah di perlukan. Tidak hanya itu, latihan dan praktek bermain drama pun harus lebih ditingkatkan. Selain bimbingan dan latihan, media pembelajaran seperti video-video drama, kostum dan benda-benda yang dapat menampakkan latar dan kegiatan dalam cerita harus dapat disediakan.

\section{Temuan Khusus Penelitian}

Dari hasil observasi dan
wawancara yang dilakukan pada
siswa kelas $\mathrm{V}$ SD Inpres 2
Rusakencana peneliti mendapatkan
temuan khusus, ternyata sebagian

dari 20 jumlah siswa sudah memahami materi drama dan cukup mampu dalam memerankan salah satu tokoh dalam cerita, namun sebagian kurang mampu bermain drama. Adapun faktor penyebabnya adalah sebagai berikut:

1. Siswa tidak percaya diri dalam berakting.

2. Takut atau tidak terbiasa berbicara di depan kelas.

3. Kurangnya bimbingan dan latihan bermain drama.

Adapun dari hasil wawancara guru, cara mengatasi kesulitan siswa bermain drama dengan menggunakan metode ceramah dan demostrasi, namun untuk kali ini guru akan menggunakan teknik role playing, sehingga hal yang di perhatikan guru dalam teknik ini adalah:

1. Menyediakan naskah drama untuk tiap-tiap kelompok.

2. Memberikan peran yang berbeda agar siswa berani bertanya jika belum mengerti dan memiliki tanggung jawab terhadap peran yang diberikan.

3. Melatih dan membimbing siswa dalam bermain drama. 
Dari hasil penelitian yang diperoleh, kemampuan siswa dapat dilihat pada tebel di bawah ini. siswa atau $40 \%$ dari jumlah siswa kurang mampu dan 0 siswa yang tidak mampu.

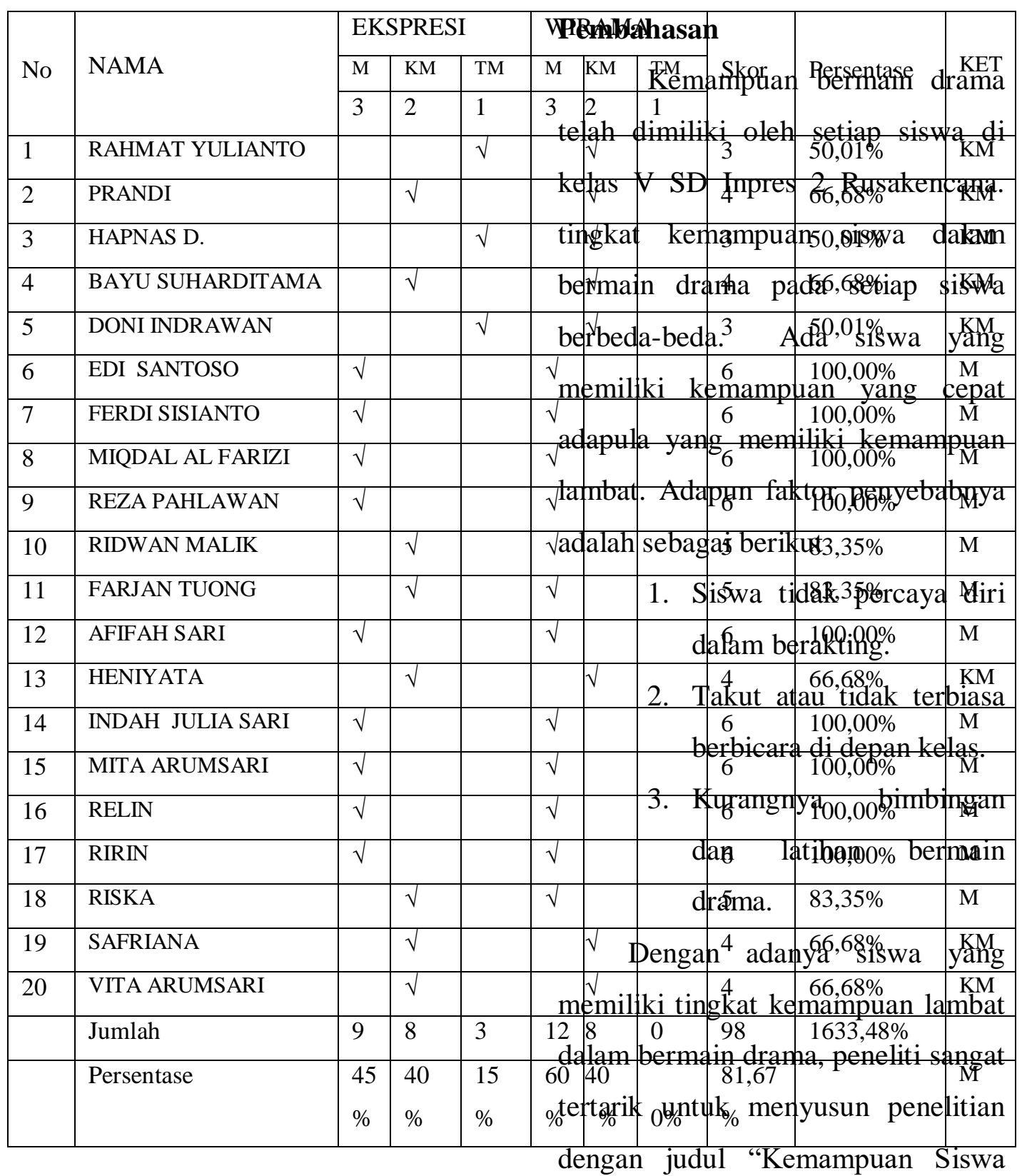

Berdasarkan tabel di atas Bermain Drama di Kelas V SD secara klasikal kemampuan siswa kelas V secara keseluruhan yaitu 12 siswa atau $60 \%$ dari jumlah siswa sudah mampu bermain drama, 8 Inpres 2 Rusakencana Kabupaten Banggai Provinsi Sulawesi Tengah".Cara yang di gunakan guru dalam mengatasi hal ini, yaitu 
dengan menampilkan contoh-contoh drama melalui audio visual, mendemonstrasikan cara bermain drama, serta menerapakan teknik pembelajaran role playing yaitu siswa memerankan tokoh dalam drama. Selain itu, guru menciptakan suasana yang menyenangkan agar dapat menarik minat siswa untuk berbicara sehingga dapat memotivasi mereka untuk membiasakan diri bertanya tentang hal-hal yang belum dipahami dan menjawab pertanyaan secara lisan. Pemberian bimbingan dan latihan baik secara individu ataupun kelompok kecil dapat dilakukan untuk meminimkan adanya siswa yang lambat dalam belajar. Dengan demikian, kemampuan siswa khususnya pada materi drama dapat tercapai sesuai tujuan pembelajaran yang diharapkan.

Dari hasil observasi, terdapat siswa yang kurang mampu bermain drama. mereka adalah Rahmat Yulianto, Prandi, Hapnas Dewantoro, Bayu suharditama, Doni Indrawa, Heniyata, Safriana dan Vita Arumsari. Kesulitan yang di temukan sangat bervariasi, misalnya mereka mampu berbicara dengan lafal/wirama yang benar tetapi belum mampu menghayati perannya. Ada pula yang mampu berbicara dengan wirama yang tepat akan tetapi tidak percaya diri saat tampil di depan kelas. Selain itu ada juga siswa yang memang kurang mampu berbicara dengan menggunakan bahasa indonesia dengan baik dikarenaka siswa tersebut sering menggunakan bahasa ibu di lingkungan rumah atau pun saat berinteraksi dengan temantemannya di sekolah.selain itu terdapat pula siswa yang berani tampil di depan kelas, mampu berbicara dengan wirama yang sesuai, namun belum mampu melakukan akting dengan ekspresi yang sesuai. Untuk mengatasi hal ini, guru melakukan tindakan dengan melakukan bimbingan dan latihan secara individual. Meskipun demikian tindakan ini tidak mempengaruhi perhatian guru terhadap siswa yang lainnya.

\section{E.KESIMPULAN}

Berdasarkan hasil penelitian dapat simpulkan bahwa kemampuan siswa dalam bermain drama sudah 
mencapai hasil yang diharapkan. Sesuai hasil penelitian kemampuan siswa bermain drama secara keseluruhan di kelas $\mathrm{V}$ yaitu sekitar12 siswa atau 60\% dari jumlah siswa sudah mampu bermain drama, 8siswa atau $40 \%$ dari jumlah siswa kurang mampu dan 0 siswa tidak mampu.

\section{Saran}

Berdasarkan kesimpulan di atas, maka dapat dikemukakan saransaran sebagai berikut:

\section{a. guru}

Hendaknya dalam mengajar Guru menggunakan metode atau teknik pembelajaran yang tepat, dapat memberikan bimbingan secara individual ataupun kelompok serta memberikan tugas-tugas dan latihanlatihan yang dapat memberikan kesempatan siswa untuk belajar.

\section{b. siswa}

\section{Siswa}

memperhatikan dan memahami penjelasan guru, membiasakan bertanya tentang sesuatu yang kurang dipahami dan bertanggung jawab terhadap tugas-tugas yang diberikan. Selain itu, sering melakukan latihan latihan khususnya pada materi bermain drama.

\section{c. Sekolah}

Untuk meningkatkan kemampuan siswa, diperlukan penyusunan program pembelajaran dengan menggunakan teknik pembelajaran yang tepat dan memfasilitasi setiap proses pembelajaran dengan media dan sumber belajar sebanyak-banyaknya.

\section{d. Peneliti}

sUntuk peneliti di harapkan dapat memperhatikan cara guru mengajar dalam proses belajar mengajar karena ilmu yang peneliti peroleh saat penelitian dapat diaplikasikan apabila sudah menjadi guru nanti.

\section{REFERENSI}

Andiz. 2013. Apa Yang Dimaksud Data Primer dan Data Skunder?. http://www.geogle.co.id/tanya/t hread?clk=relqtp\&tid=0def426 a93e2263d. 3 Maret 2014

Crespo, P. L. 2011. Unsur-unsur aintrinsik dan Ekstrinsik Drama. (Online). http://putracrespo.blogspot.co 
$\underline{\mathrm{m} / 2013 / 05 / \text { unsur-unsur- }}$

intrinsik-dan-

ekstrinsik 31.html. di akses 9 januari 2014.

Gunawan, I. 2013. Metode Penelitian Kualitatif Teori dan Praktik. Bumi Aksara. Malang.

Satoto, S. 2012. Analisis Drama \& Teater. OMBAK. Yogyakarta.

Setyawan, H. 2011. Pengertian Metode Kualitatif dan Metode Kuantitatif.http://zonainfosemu a.blogspot.com/2011/01/penger tian-metode-penelitiankualitatif.html. 3 Maret 2014.

Suciyanti, C. 2010. JENIS-JENIS DRAMA. (Online). http://dramakreasi.blogspot.co $\mathrm{m} / 2010 / 04 /$ jenis-jenisdrama.html, di akses 9 januari 2014.

Suryana, C. 2010. Data dan Jenis Data Penelitian. (Online). http://csuryana.wordpress.com/ 2010/03/25/data-dan-jenisdata-penelitian/. Di akses 3 maret 2014.

Tukan.P. 2007. Mahir Berbahasa Indonesia 2 SMA kelas XI. Jakarta: Yudistira

Wiyanto, A. 2005. Terampil bermain Drama . Grasindo.

Yusdi, M.2011. pengertian Kemampuan.(online).

http://www.milmanyusdi.blogs pot.com/2011/07/pengertiankemampuan.html?m=1\#!/2011/ 07/pengertan-

kemampuan.html. di akses 26 April 2014

Yustinah dan A. Iskak. 2008. Bahasa untuk SMA dan MAK Kelas $X I I$. Erlangga. Yogyakarta.

2014. Panduan Karya Tulis Ilmiah. Universitas Negeri Gorontalo. Gorontalo.

Indonesia Tataran unggul 